\title{
NIGERIA: \\ Understanding Boko Haram
}

\author{
Etienne LOCK
}

\begin{abstract}
This article is a contribution to the study of the Boko Haram insurgency in Nigeria. It aims to demonstrate that the ethnic identity issues in Nigeria can provide elements in understanding Boko Haram as a contextual phenomenon. Indeed, this terrorist group has taken advantage of a fragile social context fueled by problems related to ethnic identity, for its emergence and its development. These problems are also related to religion which is connected to ethnic identities and which is an important component in the Boko Haram crisis, within the Nigerian political context mainly expressed in the federalism and its consequences. From an analysis of the way problems related to different ethnic groups in Nigeria have been handled since colonial time, the article shows that the concept "Boko Haram" itself depends on this particular context which in its turn enlightens Boko Haram's terrorist actions.
\end{abstract}

Keywords: Nigeria, ethnic identity, federalism, insurgency, Boko Haram.

\section{Introduction}

Since 2010, many reflections on the Boko Haram crisis have been released in two directions. Some reflections have mainly highlighted Boko Haram in relation with the global terrorism and a strain of radical Islam, emphasising its violent actions and its consequences in Nigeria and neighbouring countries. Other reflections have proposed ways to counter this unprecedented violent movement.

However, those reflections have not sufficiently considered the ethnic identity issues in Nigeria, for the understanding of the Boko Haram crisis. Yet, the integration of different ethnic components of Nigeria in building a nation has appeared as a constant challenge since independence. Therefore, the issues of

\author{
Etienne LOCK \\ Department of Political and International \\ Studies, Rhodes University \\ E-mail: lock_etienne@yahoo.fr. \\ Conflict Studies Quarterly
}

Issue 30, January 2020, pp. 72-86

DOI:10.24193/csq.30.4

Published First Online: 05/01/2020 
ethnic identity and the Nigerian political history are connected. Because this history is also marked by conflicts, one can establish some relation between conflicts extended to security problems and ethnic identity issues. Moreover, generally considered, the ethnic identity is strongly linked to religious identity: for instance, while the northerners in their majority are considered as Muslims, the southerners in their majority are also considered as Christians. However, beyond these generalizations, the reality is more complex and it is in this complex reality of ethnic/religious identity that Boko Haram has also to be considered, and its actions analyzed. Therefore, how does the analysis of ethnic identity issues in Nigeria lead to the understanding of Boko Haram?

In reference to that question, the current reflection recalls some aspects of the Nigerian political history also characterized by ethnic identity claims. The article will first emphasize how the ethnic identity issues remain present and prevailing in Nigeria, then it will demonstrate that the Nigerian federalism is a perfect manifestation of the ethnic identity problems in that country. Finally, this reflection will focus on the way ethnic identity problems in Nigeria enlighten the comprehension of Boko Haram in Northern Nigeria.

\section{The ethnic identity issues in Nigeria}

Nigeria as a modern state seems have been built on ethnic considerations. These considerations have an impact on policy, economy and social development (Badru, 2010, p. 159). It is one of the most diversified countries in sub-Saharan Africa, with its about 350 ethnic groups (Babalola, 2015, p. 75). These groups can be divided into two groups: the majority groups and those considered as minorities. Those two kinds of ethnic groups are in competition over land, political power, economic resources, and official appointments. This makes Nigeria a kind of arena where many ethnic claims are often louder than the common national interest (Attah, 2013, p. 607).

Understanding such a landscape requires a brief back to history. As a British colonial territory, Nigeria was created in 1914, from the policy of amalgamation conducted by Lord Frederick Lugard. He merged former British protectorates previously administrated independently and having not common characteristics or very little, and brought together different peoples having different backgrounds in a single territory, just for the British vested interests and in order to promote a low cost colonial administration (Badru, 2010, p. 158). The representative government of 1951 was based on ethnic groups, and so on religious belonging due to the conjunction between ethnic identity and religion (Solomon, 2013, p. 430). Moreover, three regions were created following the peoples already identified as hegemonic: the northern region with the Hausa-Fulani, the eastern region with the Igbo and the western region with the Yoruba. It remains difficult to precise the objective criteria which prevailed in designating those ethnic groups as majority groups, for a rigorous census preceding this has not yet been established. However, this generated de facto another problem not yet known hitherto: 
the minorities, with some consequences. Olu-Olu underlined it, as far as the creation of the hegemony of the Hausa in the region of the Middle belt is concerned: "In the middle belt the peaceful coexistence of the middle belters (such as the Tiv, Idoma, Agatu, Erulo, Nyifon) to mention a few were thwarted by the infiltration of the British and its installation of the Hausa hegemonic." (Olu-Olu, 2015, p. 217). According to Attah the categories of majority and minority are strictly a colonial creation in the Nigerian context, where such a distinction was not known before: "Historically, ethnic identities in Nigeria have been categorised into the two broad majority and minority groups (...) Prior to these categorisations, there were neither major, nor minor groups distinctions." (Attah, 2013, p. 610).

The independence process espoused ethnic identities lines, through the political parties created on the basis of the majority groups in their regions: the Northern People's Congress (NPC) for Hausa-Fulani led by Ahmadu Bello, the National Council of Nigeria and the Cameroon (NCNC) for Igbo led by Nnamdi Azikiwe and the Action Group for Yoruba whose head was Obafemi Awolowo. Therefore, even if the political parties were demanding political emancipation and self-government, they were already in competition for the interests of their particular regions and so the majority groups (Badru, 2010, p. 160). Were those political parties able to express the voices of other peoples? The answer to that question may be connected to the exclusiveness each majority group gave to itself in controlling Nigeria as a big country, by excluding others: "While the Hausa Fulani believe that they were born to rule and therefore should hold on to political power, the Yoruba were of the opinion that power belongs to the educated while the Igbo believe that they should control commerce..." (Olu-Olu, 2015, p. 222). In such a context, one can understand the increasing claims of minority groups for more access to political life, economic resources and development plans. This context has also become conducive to manipulation of the Nigerian diversity by politicians in competition (Abubakar, 2001, p. 32).

As for religion, its connection to ethnic identity is rooted in the history and the sociology of each great region of Nigeria, where religion has contributed to shape the peoples identity and where it appears as a distinctive feature (Basedau, Vüllers and Körner, 2013, p. 866). Therefore, the North - due to the legacy of the Sokoto caliphate (1804-1903) and the figure of Usman Dan Fodio who imposed Islam there - is identified as a Muslim region, because Hausa-Fulani are mostly Muslims. This general identification ignores some exceptions which might exist amongst Hausa-Fulani and other ethnic groups (minorities) which may have other religious beliefs. The same situation is observed in the South-East identified as a Christian territory, due to the Igbo ethnic group identified as Christian. This type of classification where minorities are practically absent simply shows how religion contributes to the complexity of the ethnic identity issues. 
Therefore, dealing with ethnic identity is also dealing with religious belonging. In some cases, the struggle of an ethnic group in order to achieve a political ambition or an economy and social development is seen as an advantage for a religion. The connection between religion and ethnic identity is more complicated, due to the fact that there are generally several trends in the same religion: in Islam for instance, there are Sunni, Shia, Salafiyyah groups...; in Christianity there are many Christian tendencies. The access to economic resources and political positions arouses many claims from minority groups and even creates other minorities within the already known majority groups. Nigeria overcomes this complex situation that challenges its stability and the national cohesion - as the war of secession in the Biafra did between 1967 and 1970 - by often using violence against ethnic groups (Olu-Olu, 2015, p. 223). Another way Nigeria handles the problems related to ethnic identity, is to go further in establishing its federalism.

\section{The Nigerian federalism}

Nigeria is, in the $21^{\text {st }}$ century, one of the remaining African countries with a federal organisation and governance. The particularity of the Nigerian federalism is on the one hand, related to the British colonial administration. On the other hand, Nigerian federalism is an important deal with ethnic identity issues: "Promotors of the idea were of the view that the interests of the ethnic minorities in the country would be better protected under a federal political arrangement." (Babalola, 2015, p. 75). Indeed the Nigerian federalism took a policy of balance after independence, applied to its ethnic components and its regions. However, this contributed to fuel ethnic competition for more access to power and resources, overshadowing national integration the Nigerian federalism also intended to promote in a context of diversity (Suberu, 2001, p. 1). Therefore, the federal organisation became strongly connected to ethnic identity issues, which continues today (Osadolor, 2010, p. 196).

If the first constituent units were created in relation to the hegemony of the HausaFulani, the Igbo and the Yoruba, the latter units weakened this hegemony. The current policy in that regard seems to be oriented in order to make sure that any of these majority groups could not represent the overwhelming majority in any of the Nigerian states: "The incongruence between ethnic and state boundaries in Nigeria is not the result of a natural divergence between ethnic and territorial identities (...) Rather, the divergence of ethnic and state boundaries in Nigeria has resulted from a federalist state-building strategy that has sought to break up the country's three major ethnic groups into several states and to substitute ostensibly innocuous administrative divisions for presumably more fraught ethnic identities." (Suberu, 2001, p. 80; Jinadu, 2002, p. 6).

The importance of the ethnic identity issues into the Nigerian federalism is also expressed by the "federal character" established in the 1979 Constitution and reaffirmed in the 1989 and 1999 Constitutions (Adesoji and Aloa, 2009, p. 158; Dibua, 2011, p. 11). 
According to the "federal character", any appointment in National Government is based on the states' representations, rather than ethnic or regional (referring to the former great regions). Yet, since the states constituents in the Nigerian federalism are aligned with the ethnic identity issues, the "federal character" makes the federal state policy focused on ethnic groups. Historically, the interweaving between federalism and ethnic identity highlights political manoeuvring in dividing the country into many states, as it was the case when the western region was portioned into two parts in 1963 with the creation of the Middle West just to weaken the Yoruba dynamism, or when the issue of the creation of the states was tackled by the military regimes.

Some scholars have supported the Nigerian federalism in its current implementation, arguing that because of the diversity - geographical as well as ethnic - of the country, federalism is the adequate way for the political organisation of this country (Adamalekun and Kincad, 1991, p. 188). This position seems to ignore the colonial legacy and its continuous effects on the ethnic cleavages created and complicated (Badru, 2010, p. 159; Attah, 2013, p. 612). Moreover, many countries in Africa are not federal like Nigeria, but have diverse peoples, languages and cultures. So, the federal system is not a panacea to solve problems related to ethnic diversity.

The "federal character" which has reinforced the claims of many minority groups of the country is also connected to another kind of group cleavage, opposing satisfied people and those who are dissatisfied of the policy conducted by the federal state and its constituencies. Satisfied people are those who can access to power or economic resources, and dissatisfied people are those far from political power and resources. Actually, the connection between federalism and ethnic identity has strengthened the feeling of belonging to a particular group as more important than belonging to a nation where many groups coexist. In such a context, the success or the appointment of one of the members of a given group is considered as the success of the entire community, which is therefore in the position of satisfaction, though this kind of success remains individual. Satisfaction and dissatisfaction are therefore other parameters in the comprehension of the complexity of the identity issues in Nigeria relatively to federalism.

The Nigerian federalism has certainly some success, but the insufficiencies are numerous due to corruption and manipulation of ethnic identities by politicians bereft of political bid, as emphasized by many scholars like Solomon pointing out a bad leadership: "Nigeria has been beset with a leadership which (...) has no idea of Nigeria and no notion of Nigeria as a spatial and structural instrument of the construction, expansion and popularisation of egalitarian social life. Far from attempting to overcome these divides, Nigeria's political (and military) mandarins have cynically exploited the country's fault lines - whether regional, religious or ethnic - for personal advantage." (Solomon, 2013, p. 430). 
This has led the federalism in Nigeria to a fragile organisation which bears the risk of its collapse as demonstrated by new current claims such as the Biafra independence justified by the "Igbo marginalisation" (Badru, 2010, pp. 163-164). Some other regions might join this inclination to secession. Besides, there are many other calls for more states in Nigeria because of the growing of the willingness to access to the "national cake". Therefore, the future is in question: "Unless some structural or fundamental means can be found to discourage the process, the creation of new states and localities may become, in Olusegun Obasanjo's opinion, 'an endless joke which will continue to reduce the viability of our federalism."' (Suberu, 2001, p. 110). Due to the strong connection between federalism and ethnic identity, the better would be to questioning federalism as political organisation suitable to Nigeria or to rethinking Nigerian identity in the frame of the national cohesion and a real citizenship which could overcome problems such as indigene-settler relation.

\section{The indigene-settler issue}

The indigene-settler issue appears as one of the most important consequences of the Nigerian federalism (Jinadu, 2002, p. 35). Indeed, having mainly been based on the ethnic identity issues this has contributed to establish the indigene-settler issue, referring to the dialectic of "son of the soil" meaning "natives or indigenes" versus "settlers or foreigners." (Alubo, 2008, p. 1). This dialectic is related to privileges or access to privileges.

Yet, it is important to stress that Nigeria is not the only country in Africa where disputes between natives and settlers exist. In Cameroon for instance, similar problems do exist since some decades; and a city like Douala has witnessed the claims of the so-called natives over land and some administrative positions. The state policy to solve this issue is to appoint natives in some government positions in local level. An example is the position of Délégué du gouvernement auprès de la Communauté urbaine who represents the government in a big city as a "super mayor". The person in that position is a senior official in charge of the municipalities' affairs and he/she is above the mayors who are elected by the populations. ${ }^{1}$ In Douala, in Yaoundé, in Bafoussam, and in other big cities elsewhere in Cameroon, the incumbent of this position is always a "native" appointed by the President of the Republic, without considering the skills required by the position: the only purpose is to satisfy the claims of "natives". In the national level, the policy of regional balance outweighs the requirement of competencies and even creates some injustice. For instance, the competitions for enrolment in schools training the senior officials is driven by that policy of regional balance, instead of promoting a

1 Cameroon seems to be the only case in the world where such an inconsistency is observed. It is seen as an impediment to democracy, since the position has been created and reinforced in the 1990s by Paul Biya, the President of the Republic, to counter the mayors then elected and who were coming from the political parties of opposition. 
recruitment on the basis of the merit, as the scandal of the Cameroonian Institute for International Relations (IRIC) has clearly demonstrated in 2015 with the Minister of Higher Education, Professor Jacques Fame Ndongo. ${ }^{2}$ Similar things are observed in some other African countries, where the ethnic identity plays an important role for political positions (Badru, 2010, pp. 149-169).

In the Nigerian case, the fact that the federalism is aligned with ethnic identity issues has opened the way to many interpretations and practices of exclusion: "The 1979 Constitution from which the 1999 Constitution was modified has been seen as laying the basis or foundation for the indigeneship problems. This is because it expressly provides that in order to enjoy access to positions and opportunities on the basis of 'federal character' one needs to be an 'indigene' of the state or local government concerned." (Adesoji and Aloa, 2009, p. 158).

The same comprehension of the 1999 Constitution related to the indigene-settler issue has been presented by Alubo (Alubo, 2008, p. 5). In the federated states of Nigeria, the competition over access to schools, lands, scholarships, civil positions..., etc, is in priority opened to the "natives" of these states. One could hypothesize that this measure has been taken in order to allow the minorities to have the same opportunities as the identified majority groups. However, the indigene-settler issue has definitely generated many other problems that question citizenship in Nigeria and create other discriminations remaining unsolved.

The indigene-settler issue in Nigeria is not only a question addressed to the citizenship, but also a challenge vis-à-vis the citizenship and even a threat upon it. Indeed how is it possible to conceive a citizenship in a Federal Republic and articulated to the indigenesettler problem? Some scholars as Dibua in the wake of Momoh have identified three categories of citizenship in Nigeria: constitutional citizenship, ethnic citizenship and diasporic citizenship (Dibua, 2011, p. 4). Dibua even considered a fourth category based on the sharia, for its implementation and influence in the northern states of Nigeria (Dibua, 2011, p. 5). In the same vein, the contest between citizenship and indigeneship leading to other forms of citizenship has been presented by Nwosu (Nwosu, 2008, p. 83). However, amongst the citizenships identified, the most efficient seems to be the one connected to ethnic identity, which also overlaps with religion (Harnischfeger, 2004, p. 443).

Relatively to the concept of foreigner, the indigene-settler issue seems to be rooted in some Nigerian peoples' traditions such as Yoruba. As Akanji has stressed it, in the Yoruba pre-colonial society the dichotomy indigene-settler was already present and was

2 For this competition, three different lists of the results had been published and the names of some laureates deleted and replaced by those who were unsuccessful. The Minister explained the changing of the lists by the necessity of the regional balance, which in Cameroon refers to an ethnic identity issue. 
concerning the land. More precisely a stranger or foreigner was (and is still) a person who could not claim the land. Thus, the title of foreigner was devoted to those who were farming or fishing in an area, namely a piece of land, which was not belonging to them (Akanji, 2011, p. 119).

All what precedes suggests that being Nigerian would be firstly belonging to a particular ethnic group located somewhere in Nigeria; this means being a "native" from somewhere: "Certificates of state and/or local council indigene have become prerequisites for a wide array of opportunities such as admission to schools and employment even as the conditions for obtaining these are immutable." (Alubo, 2008, p. 8). Therefore, what about Nigerians without such references, since according to the constitution the citizenship can also be acquired by naturalisation of people coming from outside Nigeria? Another issue raised here is the situation of women. Indeed, the dialectic indigenesettler seems to ignore the women getting married in the states other than theirs. According to the traditions of Nigerian peoples and even the Nigerian constitution, a woman who gets married to a man belongs henceforth to her husband people; but she is not obviously considered such as, when comes the time for access to employment, political positions or scholarships. Women sometimes need to return to their states of origin where they have priority in competitions regarding official positions or scholarships.

The indigene-settler issue has already triggered many riots in many Nigerian states as well as violent disputes between peoples of different ethnic groups of the same state. While the natives consider themselves as having all the rights, the settlers do not always consider themselves as foreigners, because in Nigeria the concept of settler is very changing, also depending on the kind of relations different groups have with each other in a same state (Akanji, 2011, p. 119). Therefore, who is actually a settler? After a century of settlement is it right to continue to be considered as a settler, meaning a foreigner? Those questions suggest that the distinction between natives and settlers can be problematic in some cases (Adesoji and Aloa, 2009, p. 154).

The indigene-settler issue seems very far from its end, for the problems related to ethnic identity are still present; they are even increasingly reinforced. It would be therefore important for Nigeria to revise such a disposition and even to fight against the official practice of discrimination related to the indigene-settler issue. From this complex issue, it seems easier to define an ethnic identity like the Igbo, the Tiv, or the Yoruba, than to define the Nigerian citizenship.

\section{"Boko Haram" within the ethnic identity issues}

Many scholars working on the African insurgencies and more specifically on Boko Haram, have practically the same definition of the concept "Boko Haram" itself. Even though some of them consider the concept as combining Hausa and Arabic words re- 
spectively while for others the concept is totally from Hausa language, they agree on the same translation and definition. Their common definition of Boko Haram is linked to the relation between that terrorist group and anything from the West or connected to the so-called "modern civilisation". One has for instance, Aghedo and Osumah translating Boko Haram by the evil character of western education (Aghedo and Osumah, 2012, p. 858); and Murtada defining Boko Haram as opposed to the western educational system (Murtada, 2013). For Akanji the group's name is connected to western education as something forbidden (Akanji, 2015, p. 61). More recently, Alozieuwa has translated the concept as "Western Civilization is forbidden" (Alozieuwa, 2016, p. 50); Iyekekpolo has defined Boko Haram vis-à-vis the western education, which is considered sinful (Iyekekpolo, 2016).

All those definitions given to the concept "Boko Haram" seem to ignore the very reality of the ethnic group issues in Nigeria. Indeed, the scholars above have separated "Boko Haram" from the Nigerian reality, which needs to be taken into account in the definition of this terrorist group. Otherwise, how can a Nigerian phenomenon be only linked to the West, while history, politics and even sociology of Nigeria are able to provide explanations to any problem emerging from the particular context of that country? Boko Haram is first and foremost a contextual insurgency. Therefore, its comprehension requires a consideration of its context of appearance and development which is the northern Nigeria, fashioned and still influenced by ethnic identity issues. Moreover, the definition of "Boko" in relation to the West seems mostly related to the connection established between "Boko" and "book" symbolising the western education or more widely the western civilization. On this particular issue of book, one should mention that attributing the concept "book" exclusively to the West appears as a mistake, for the Muslim tradition in which most of the peoples of the Northern Nigeria are rooted, also knew books and many scholars, especially during the time of the Sokoto Caliphate.

According to Professor Mohammed Munkaila of the University of Maiduguri, one of the leading linguists of the Hausa language, "Boko" is not related to "book" as some scholars have argued. As far as the concept "Haram" is concerned, there is a consensus over its meaning, although some little differences could be noted on its translation. Indeed, "Haram" defined or translated as forbidden, sinful, bad, or rejected, indicates the same thing, qualifies something in the same way. Therefore, the word that needs clarification in the concept "Boko Haram", is "Boko" due to the above-mentioned disagreement over its translation.

In A Hausa-English Dictionary edited by Newman and recognized as "the dictionary of choice for Hausa-language scholars" (Buba, 2008, p. 458), the concept "Boko" has four senses: western education, Latin alphabet (especially as contrasted with the Arabic alphabet for writing Hausa), secular, and fraud (Newman, 2007, pp. 22-23). Amongst them, only the fourth sense could be considered as not related to a particular civilization 
or cultural issues. Indeed, "western education" and "Latin alphabet" are related to the western civilization, while "secular" is linked to a particular society according to the importance and the place given to religion in that society. Thus "secular" gives some cultural references. For instance, France is a secular country because of the neutrality of the state vis-à-vis religion; and the French secularism is one of the most important components of the French culture.

As for the fraud that also means here deceit, it is something rather connected to the common morality and rejected in any culture and by all civilizations. Therefore, the problem about "Boko" lies in the three first senses of the dictionary edited by Newman. Since those senses have something to do with cultural issues, and particularly the western culture (western education, Latin alphabet and secularism are related to the peoples of the West), one can link them to the encounter between Hausa and western peoples. Thereby, the understanding of "Boko" also needs to be situated in the history of the encounter between the West and the African continent, particularly in Northern Nigeria.

The concept "Boko" arose in a context of fundamental intellectual reaction by Islamic ulema against European or western imperialism, based on cultural domination, during the colonial time. Indeed, as the colonial expansion was an enterprise aiming to impose the "civilisation" made up of the western ideologies, the western way of life, and the western religion namely Christianity, the intellectual (and even the military) reaction within the Muslim communities was to protect the Muslim religion as well as the Muslim tradition: this also meant protecting ethnic identities fashioned by Islam as a religion. In Nigeria for instance, the struggle of the Muslim authorities, after the conquest of Sokoto in 1903 by the British colonial army, was to keep the Muslim community away from the proselytizing of the Christian missionaries. Indeed these missionaries sought to convert Muslims, in spite of the policy of the British colonial administration of impeding this (Sodiq, 2009, p. 650; Barnes, 2010, p. 442). It should be noted that the reaction of Islamic ulema against European domination was not because the imperialism was European or western, but firstly because this was something foreign and able to disturb the way of life in Muslim communities and Muslim religion. That explains some movements of resistance as the one carried out by Samory Touré against the European expansion in Africa (Peterson, 2008, pp. 261-279). Thus, it is obvious that even if the imperialism or the cultural domination as a threat came from Asia, from America or from elsewhere, the reaction would have been the same in order to protect Muslim communities.

Therefore, the concept "Boko" appears as strongly connected to what is foreign or what is related to foreign influence, for that comes from outside and it is able to disturb the organisation of the Muslim communities whether in Nigeria or elsewhere in subSaharan Africa. However, inside Nigeria, the concept "foreign" itself is very ambiguous, especially when one considers the ethnic identity issues, the Nigerian federalism and the indigene-settler issue. From these issues that characterize the Nigerian political, 
historical and sociological context, as demonstrated with the "federal character" and its interpretation, a foreigner is not only a person coming from outside Nigeria. In fact, from one constituent state of the Federal Republic of Nigeria to another, a foreigner might also be a Nigerian in Nigeria. Thus, a Nigerian settler or non-indigene is indeed a foreigner somewhere in Nigeria.

"Boko" in Nigeria has to be taken in a sense which considers the situations presented above. In northern Nigeria, and relatively to Muslim communities, a foreigner can also be a northerner who is not Muslim or who is not practicing Islam in a certain manner. This could appear as an extremist position; yet, it is important to remind that the Northern Nigeria is mostly established in the legacy of the Sokoto caliphate and its main figure Usman Dan Fodio who led a jihad against the political Muslim class he considered "stranger", due to its un-Islamic behaviour (Iyekekpolo, 2016). The northern Nigeria is therefore seen as a Muslim territory, and this could explain some political orientations taken, regardless those who are not Muslims, as it was the case in a northern state of Nigeria, when the "Governor of Zamfara announced plans in 1999 to implement 'full Shari'a' in his state." (Thurston, 2015, p. 28).

In northern Nigeria, the concept "Boko" related to "foreign" is also related to people who are not from that part of the country, as it was during the colonial era, when they could not settle inside some towns because of their way of life that did not comply with the requirements of living in the North. In Kano for instance, this kind of people had to settle outside the city (Akanji, 2011, p. 120). This practice was supported and even encouraged by the British colonial administration which, with its policy of indirect rule, also maintained the religious, political and traditional organisation established many decades before by the Sokoto caliphate. Thus, the concept "Boko" would not only be applied to people, but also to some ways of life other than those prescribed in some native communities of the northern part of the country. This could even be extended to other regions or states in Nigeria.

In his recent book entitled Searching for Boko Haram: A History of Violence in Central Africa, Scott MacEachern has brought out the historical background of the region covered by Boko Haram attacks. That historical background is mainly based on resistance of whatever comes from outside and does not correspond to a certain way of practice of Islam: "The history of this region has been marked by horrific violence, indigenous adaptation and fierce resistance to outside control, and memories of that history still affect how local people understand the scourge of terrorism that Boko Haram has brought to the lands around Lake Chad." (MacEachern, 2018, p. 3). Indeed, it appears that the origins of Boko Haram "lie in a complex history of religious disputation and political competition that started centuries ago in the lands around Lake Chad." (MacEachern, 2018, p. 6). Any approach that ignores or disregards this particular background still having impact in the present might fail to provide a sufficient explanation and a thorough 
understanding of Boko Haram. The perspicacity of MacEachern's book is also shown by his definition of the concept Boko Haram, which corresponds to the approach given above and which differs from what is commonly said: "Boko Haram' might thus more accurately be translated by 'Deceitful education is forbidden', which does not fit quite as well with western reductionist images of the group as fundamentally ignorant and backward." (MacEachern, 2018, p. 11).

Boko Haram appears therefore as a terrorist group that not only is rooted in a tradition of violence, but that also takes advantage of the complex situation of ethnic identity issues based on competition in Nigeria, in order to impose its disastrous agenda. The group seems to be entrenched in the prohibition of all what does not correspond to the northern Nigeria and to the principles of a radical and fundamentalist Islam. Thus, Boko Haram combines religion and region, which are also the crucible of many internal conflicts in Nigeria.

Relatively to the ethnic identity issue, this seems to be aligned with the mindset of many northerners represented by Ahmadu Bello, the Sardauna of Sokoto, during the independence campaign and even before, within the Northern People's Congress (NPC). The objective openly presented by the party was to put the northerners in the positions of the political power (Elaigwu and Galadima, 2003, p. 129). Due to this tradition of only caring about the northern region, it seems relevant to hypothesize that Boko Haram is not a movement whose aim is to conquer Nigeria, but certainly to recover the authentic northern Nigeria with probably the frontiers of the Sokoto caliphate which was a dominated Hausa-Fulani empire. Inasmuch that empire blanketed some current neighboring countries like Cameroon, one can understand why Boko Haram is active in Northern Cameroon and even why some northern Cameroonians have found themselves involved in Boko Haram actions. Indeed Boko Haram also plays with the feelings of the trans-border peoples brought out in a study conducted by Ikechi Onah: "This study has shown clearly that fractions of trans-border groups are effectively prevented from involvement in the commanding heights of the economy and politics of any one of the countries in which they live, the tendency is always for them to see the larger ethnic group as the alternative, hence their increased attachment to the group and solidarity with other fractions in the other countries." (Ikechi Onah, 2015, p. 90).

All what precedes could also explain the attacks of Boko Haram against people who are not Hausa-Fulani and Muslims, and even against those who are Hausa-Fulani but far from the fundamentalism: "In Nigeria, despite the popular portrayal of the Muslim Boko Haram attacking Christians, extensive research by Human Rights Watch on the victims of Boko Haram violence found that the Hausa-Fulani Boko Haram were targeting victims on the basis of not only their religion but also their ethnicity (largely Yoruba and Igbo)." (Solomon, 2013, p. 432; see also Aghedo and Osumah, 2012, p. 859; Attah, 2013, p. 617). Moreover, the general context of Nigeria regarding ethnic identity issues 
is very conducive to the doctrine of Boko Haram, since the "son/daughter of the soil syndrome" seems to play its game in northern Nigeria (Jinadu, 2002, p. 37). It is in the same way that one can understand the position of Boko Haram against the western or modern civilisation, expressed in the destruction of the schools and other modern facilities which remind the western influence in Nigeria (Murtada, 2013, p. 18).

Some scholars as Akanji have argued that Boko Haram aims to impose Islam to the whole Nigeria (Akanji, 2015, p. 62). But this is quite difficult to admit, because the predominant political tradition in the northern Nigeria since independence is to defend the interests of the northerners anywhere in Nigeria, and not to impose the North everywhere in the country. Besides, Islam in Nigeria has many different trends, and the trend claimed by the Boko Haram insurgency is a particular one. Indeed its alignment with the Islamic State is the proof of its radicalization and contributes to explain the terrorist actions led against other Muslim communities. An observation one can make is that the Nigerian context seems favorable to the development of radicalization, whether on the side of the ethnic identity or on the side of religion connected that identity. Boko Haram therefore appears as a kind of accomplishment of this, by combining both kinds of radicalization in its doctrine and its terrorist actions.

\section{Conclusion}

The ethnic identity issues in Nigeria are an important key of comprehension of its political itinerary since independence, as well as its current difficulties made up of many insurgencies observed in the North and elsewhere in the country, like in the Niger Delta. And the situation seems to be far from its end, since Nigeria needs to forecast other possible insurgencies, with the ethnic identity claims increasingly growing.

The Nigerian federalism has been presented as the response to the necessity to promote the diversity of the country and to create an atmosphere of peaceful cohabitation of different peoples, overcoming at the same time competition between ethnic groups and frustrations related to that competition. However, this federalism based on a colonial legacy which encompasses ethnic divisions and frustrations, seems not yet able to solve the ethnic problems. Moreover, considering the willingness of the Nigerian federalism to satisfy many ethnic groups presented as minorities from other minorities or from traditional majority ethnic groups, the implementation of the "federal character" and its interpretation which sometimes changes from one constituent state to another, will probably worsen the indigene-settler issue, as an institutionalized discrimination.

Those fault-lines give explanations to some inevitable conflicts in Nigeria. They are also a crucible of the Boko Haram insurgency whether in its terminology, in its agenda and its terrorist actions. The sect appears, not only as a radical religious group rooted in a particular historical context of violence and aligned with the Islamic State, but also an expression of the complex situation created by the ethnic identity problems in Nigeria. 
Thus, overcoming such an insurgency might require a serious reconsideration of these problems in which religion is not absent, due to its connection to them.

Acknowledgement. This work was supported by the grants of the Andrew W. Mellon Foundation and the Research Committee of Rhodes University.

\section{References}

1. Abubakar, D. (2001). Ethnic identity, democratization and the future of the African state: lessons from Nigeria. African Issues, 29, 31-36.

2. Adamalekun, L., \& Kincaid, J. (1991). The federal solution: assessment and prognosis for Nigeria and Africa. Publius, 4, 173-188.

3. Adesoji, A. O., \& Aloa, A. (2009). Indigeneship and citizenship in Nigeria: myth and reality. Journal of Pan African Studies, 9, 151-165.

4. Aghedo, I., \& Osumah, O. (2012). The Boko Haram uprising: how should Nigeria respond. Third World Quarterly, 5, 853-869.

5. Akanji, 0. 0. (2011). The problem of belonging: the identity question and the dilemma of nation-building in Nigeria. African identities, 2, 117-132.

6. Akanji, O. O. (2015). Security crisis in Nigeria: Boko Haram insurgency and the prospect of peace. Conflict Studies Quarterly, special issue, 58-73.

7. Akpan, N. U. (1978). Nigerian federalism: an accidental foundation by Lugard. Journal of the Historical Society of Nigeria, 2, 1-20.

8. Alozieuwa, S. O. H. (2016). Beyond political Islam: Nigeria, Boko Haram and the imperative of national consensus. Journal of retracing Africa, 2, 49-72.

9. Alubo, O. (2008). Understanding the issue in the citizenship-indigeneship crisis in Nigeria. In J. H. P. Golwa and 0. 0. Ojiji (Eds.), Dialogue on citizenship in Nigeria (pp. 1-16). Abuja: Institute for Peace and Conflict Resolution.

10. Attah, N. E. (2013). Contesting exclusion in a multi-ethnic state: rethinking ethnic nationalism in Nigeria. Social identities, 5, 607-620.

11. Babalola, D. (2015). The efficacity of federalism in a multi-ethnic state: the Nigerian experience. The Journal of Pan African Studies, 2, 74-91.

12. Badru, P. (2010). Ethnic conflict and State formation in post-colonial Africa: a comparative study of ethnic genocide in Congo, Liberia, Nigeria and Rwanda-Burundi. Journal of Third World Studies, 2, 149-169.

13. Ballard, J. A. (1971). Administrative of Nigeria federalism. African Affairs, 281, 333-348.

14. Barnes, A. E. (2010). The great prohibition: the expansion of Christianity in colonial Northern Nigeria. History Compass, 6, 440-454.

15. Basedau, M., Vüllers, J., \& Körner, P. (2013). What drives inter-religious violence? Lessons from Nigeria, Côte d'Ivoire and Tanzania. Studies in Conflict and Terrorism, 36, 857-879.

16. Buba, M. (2008). A Hausa-English Dictionary, Paul Newman: book review. Lexikos, 18, 456-462. 
17. Dibua, J. I. (2011). Ethnic citizenship, federal character and inter-group relations in postcolonial Nigeria. Journal of the Historical Society of Nigeria, 20, 1-25.

18. Elaigwu I. J., \& Galadima H. (2003). The shadow of Sharia over Nigerian federalism. Publius, 3, 123-144.

19. Harnischfeger, J. (2004). Sharia and control over territory: conflicts between 'settlers' and 'indigenes' in Nigeria. African Affairs, 412, 431-452.

20. Ikechi, O. E. (2015). The role of Trans-border ethnic groups in intra-state and interstate conflict in Africa. Journal of Borderlands Studies, 30, 85-95.

21. Iyekekpolo, W. O. (2016). Boko Haram : understanding the context. Third World Quarterly, 37, 2211-2228.

22. Jinadu, A. L. (2002). Ethnic conflict and federalism in Nigeria. Discussion papers on development policy, 49, 1-50.

23. MacEachern, S. (2018). Searching for Boko Haram: A History of Violence in Central Africa. Oxford: Oxford University Press.

24. Murtada, A. (2013). Boko Haram in Nigeria: its beginnings, principles and activities in Nigeria. SalafiManhaj.com. Retrieved from http://download.salafimanhaj.com/pdf/ SalafiManhaj_BokoHaram.pdf.

25. Newman, P. (2007). A Hausa-English Dictionary. New Haven and London: Yale University Press.

26. Nwosu, B. U. (2008). The political economy of citizenship-indigeneship controversy. In J. H. P. Golwa and 0. O. Ojiji (Eds.), Dialogue on citizenship in Nigeria (pp. 79-98). Abuja: Institute for Peace and Conflict Resolution.

27. Olu-Olu, O. (2015). Ethnic identity and the crises of development in Nigeria. European Scientific Journal, 2, 216-229.

28. Osadolor, O. B. (2010). Origin of the central dilemma in Nigeria's federal system: the war-time quasi federalism, 1967-1970. Journal of the Third World Studies, 1, 193-213.

29. Peterson, B. J. (2008). History, memory and the legacy of Samori in Southern Mali, c. 1880-1898. The Journal of African History, 2, 269-279.

30. Sodiq, Y. (2009). Can Muslims and Christians live together peacefully in Nigeria?. The Muslim World, 4, 646-688.

31. Solomon, H. (2013). The African state and the failure of US counter-terrorism initiatives in Africa: the case of Nigeria and Mali. South African Journal of International Affairs, 3, 427-445.

32. Suberu, R. T. (2001). Federalism and ethnic conflict in Nigeria. Washington: United States for Peace Press.

33. Thurston, A. (2015). Muslim politics and Shari'a in Kano State, Northern Nigeria. African Affairs, 454, 28-51. 